\title{
Literacy, Identity and Gender: A Case Study of Love Letter Writing Practices from Pakistan
}

\author{
Fatima Zafar Baig ${ }^{1} \&$ Naveed Ahmed ${ }^{2}$ \\ ${ }^{1}$ Bahauddin Zakariya University, Multan, Pakistan \\ ${ }^{2}$ Professor, Chair, Department of English, Bahauddin Zakariya University, Multan, Pakistan \\ Correspondence: Muhammad Zammad Aslam, University of Sindh, Jamshoro, Pakistan. E-mail: \\ zammad.aslam@gmail.com
}

Received: March 10, 2019 Accepted: April 16, 2019 Online Published: July 3, 2019

doi:10.5539/ijel.v9n4p288 URL: https://doi.org/10.5539/ijel.v9n4p288

\begin{abstract}
This study aims to explore the identity (ies) and ideology (ies) embedded in the love letter writing practices of the people particularly in Pakistan. It brings forth the established social and cultural practices and thoughts of the letter writers from gender perspective. This study investigates the ways in which gender identity is enacted within the language of love letters. Being a significant social literacy practice, the writing of a letter is rooted in a particular social situation. Like all other types of literacy objects and events, the activity advances its meaning and significance from being situated and positioned in cultural beliefs, values, and practices. A case study of the young Pakistani couple has been conducted in this regard where the language used by couple in their love letters is analyzed from ideological perspective. The data are comprised of the love letters which are analyzed qualitatively. Street's Ideological Model has been employed for qualitative analysis. The research finds out that the ways in which people communicate are constrained by the structures and forces of those social institutions within which they live and function. It also highlights the substantial role of language in the constructions and representations of social and cultural beliefs and values.
\end{abstract}

Keywords: Ideology, Literacy practice, literacy event, gender identity

\section{Introduction}

Formerly, the main concerns of the academic research included the cognitive outcomes of literary acquisition. In sociolinguistics, contrasts between orality and literacy as channels of communication has always been emphasized. But in the recent times, the focus has shifted to an important social practice, that is a wider inspection of literacy and the socio-political communicative roles that it plays, particularly considering cross cultural perspective.

\subsection{Traditional and Modern Approaches to Literacy}

Traditional Approach to literacy views it as an autonomous value-free characteristic lying within the individual, that is in actual, a set of particular and transferable skills which can be instructed, measured and analyzed at competence level. Traditionally, reading and writing texts formally involving rules that surrounds the use of a national language have been considered as the actual meaning of literacy. In short, this approach studies literacy as an autonomous and context-free technical skill. The model which conforms to the main postulates of traditional approach is called an 'Autonomous model'. Street (1995) calls "autonomous" model of literacy as a set of de-contextualized skills, displays limited mental operations in reference to literacy meaning, gives no attention to the formation of culturally specific concepts and philosophies lie in social structures.

Unlike traditional approach, the modern approaches view literacy as an ideological practice. It says that literacy involves culturally specific meanings and practices, and power relations. The reading and writing practices of the society signify and showcase ideology (ies) regarding its social, cultural, political and gender identity (ies). In general terms, different ideology (ies) and identity (ies) are very much explicitly reflected through literacy practices. An important shift is visualized within this framework and that is the rejection of many writers of this dominant conceptualization of literacy as a technical and neutral skill. This modern approach views literacy as something that people 'do' rather something that people 'have'. This approach is called New Literacy Studies (NLS). The NLS approach offers an unconventional, socially positioned and socially constructed view of literacy 
which is multiple, emergent and situated in particular social contexts (Barton, 2000). This approach debates how social and cultural meanings are discursively constructed through everyday activities of life. Also, it motivates the reading and writing of documents used in different activities of life to be differently talked about. This approach further points to the Ideological model of literacy by Street which says that literacy lies in contexts.

\subsection{Ideological Model}

In ideological model, Street has taken the cultural and social behavior and conceptualization that makes the reading and writing meaningful as "literary practices" instead of just literacy events of reading and writing. Contrary to autonomous model of literacy, Street proposed the ideological model. The model comprehends literacy as those social practices that exist and are present in society and then this model enables formulating these practices.

Freire (cited in Barton, 1994) explains the traditional and the new concept of literacy studies. He relates traditional literacy education with banking, where knowledge is deposited in a person. In his view, literacy is like a thing or object that can be moved from one person to another, sometimes given or sometimes received, shifting the metaphor slightly, it is like filling up empty people with some literacy. This traditional view is contrasted with ones of literacy as empowerment, as a right. It must be related to as something which people do, a process rather than as a thing that people have. Moreover, he claims that literacy is something that includes teaching of masses to think reasonably and evaluate critically, so it is not monolith. He offers the fact that there are manifold purposes for employing literacy, so that it may have domesticating effects and that it can have empowering and emancipating effects.

\subsection{Love Letter Writing as Literacy Practice}

Among all literacy practices, letter writing is considered an essential one as it is being practiced in almost every culture of the society. Also, there has been a notable rise in scholarly interest in recent years about the functional and communicative aspect of this literacy practice from a theoretical and cross-cultural viewpoint. The current research is related to the operative and pragmatic dimensions of letter writing practices. It specifically looks at the genre of love letters which is distinctive among social literacy practices. In the contemporary Pakistani culture, patriarchal structures are still strong as viewed within wider context of literacies and letter writing practices. This work explores the constructions and representations of different ideology (ies) and identity (ies) regarding femininities and masculinities. From sociolinguistic perspective, these gender ideologies are naturalized and discursively constructed in society.

\subsection{Love Letter Writing and Identity}

In order to express inner feelings to someone special, the most appropriate way one can opt is to write him/her a love letter. It allows writer to express feelings in an easier and a comfortable manner than in the presence of his/her beloved. Moreover, writing one's strong emotional feelings on paper or some other permanent form is an expression itself of love and desire. It also shows the standing of the beloved and supports the lover's emotions.

Most work on language and identity inspired in poststructuralism adopts a social constructivist perspective according to which identity is about the multiple ways in which people position themselves and are positioned, that is, the different subjectivities and subject positions they inhabit or have ascribed to them, within particular social, historical and cultural contexts (Block, 2007a, 2007b, 2009; Duff, 2012; Norton, 2010; Norton \& Toohey, 2011). Other times, especially in the past before the wide use of telecommunications, letters were one of the few ways for a couple to remain in contact.

Post structuralists view power structures and identity construction as a product of society which is discursively constructed. Moreover, they believe that identity is something that is always in a state of flux and not fixed. A person may have multifarious identities at one and the same time. And language plays a substantial role in the construction of such identities. Love letter writing being an important literacy practice is accommodating in terms of compliance of these social power relations. It also refers to the emotive functions of the written communication, as the feeling of love is one of the chief human emotions. So, does the language of love letter which reveals human emotions and feelings along with mindset and identities of the people. In earlier times, literacy of women was controlled so that they might not write love letters to strangers and express their feelings. But these restrictions could not stop them to express themselves and they continued writing love letters to their loved ones.

The current research is based on the case study method which has been conducted on a young couple aged 22 (girl) and 25(boy). The couple belongs to Pakistan which is a patriarchal society. The patriarchal structures are inculcated so deeply in their minds that even their love letter is not devoid of these impressions. Although love is 
an emotion where there are no rigid boundaries and obligations. The boy and the girl are intensely in love with each other. Nobody forced them to stay together as they have chosen each other with their own will. They are completely unrestricted and self-dependent to express their emotions. Their writings show clear evidence of patriarchal norms and practices that are instilled in their subconscious of which they might themselves are unaware.

It is evident from the analysis of their writings that even when they have freedom to express their thoughts, feelings and opinions, their writings clearly express the patriarchal structures and patterns that are prevalent in their subconscious of which they themselves are unaware.

\section{Conceptual Framework}

Like literacy, the term 'writing' has a functional and literary meaning (Mc Garry, 1991). By talking about the relationship between literacy and writing Ong (1982) claims in one of his seminal essays that: "Writing reconstructs thought'. It implies that writing depicts the ideologies and identities of individuals and is sometimes more effective than speech. One of the most significant ingredients of writing is that it supports one's attention to the core emotions associated with the topic being discussed. Expressing through written discourse gives greater insight to the thoughts and emotions under consideration (Kennedy-Moore \& Watson, 2001). The effectiveness of expressing through writing is evident in many researches. Literature shows that the benefits and outcomes of writing is vast (Frattaroli, 2006; Frisina et al., 2004; Smyth, 1998). They claim that writing is beneficial for the individuals' physical, psychological health and welfare (Pennebaker \& Chung, 2007).

For personal and social interaction in society, people may adopt verbal and non-verbal ways of communication. Within verbal communication, both written and spoken channels are employed by people. But the value of written form of communication can never be lost because of the ways it allows the emotive and communicative functions of language. Previously, it was maintained that written communication is typically less effective than oral communication (Chafe, 1982; Chafe \& Danielewicz, 1987; De vito, 1966, 1967; Redecker, 1984). According to them, the immediacy of an audience is the most significant ingredient in spoken discourse which allows speakers to invoke more personal elements in it. While owing to the lack of visible audience, writers can afford to do the same, so considerably less. Furthermore, in spoken language, linguistic features like personal pronouns, references to the speaker's mental processes ('I think that' and so on), expressions like "you know", emphatic particles, hedges and direct quotes, play an important role regarding the effectiveness of the message.

Meanwhile, the characterization of speaking as an affectively charged communicative activity has been challenged by Tannen (1982a, 1982b), Biber (1986), Besnier (1988). Tannen and Biber show that some types of writing are more affect laden than some types of speaking. So, it is clear that the fact that the data that they have typically based their research on its academic writings in which writers are expected to pose as objective and unemotional, has led earlier researcher to conclude that written language is more objective and less effective than speaking is. It is surprising that little research has focused on the structures of more run of the mill written registers like personal letters as communicative events and linguistic genres (Gillogly, 1984; Mikulecky, 1985; Mulkay, 1985; Rubinstein \& Gajdusek, 1970; Scribner \& Cole, 1981).

In recent studies, the default position as regards identity is to frame it as a social process as opposed to a determined and fixed product, following the tenets of what has come to be known as poststructuralism. Duff (2012, p. 412) outlines this position as by presenting poststructuralism as an approach that questions fixed categories or structures, oppositional binaries, closed systems, and stable-truths and embraces seeming contradictions. Moreover, it is also examined how such categories are discursively and socially constructed, taken up, resisted (the site of struggle), and so on.

So far letter writing is concerned, it has been observed that owing to the communicative purposes, primarily, people employ letter writing especially in the situations of absence. A number of pieces of research have shown that when people need to keep in touch, they not only do communicate through letters but employ its proxies also (Licoppe, 2004; Wacjam, 2008). Letter writing, including proxies such as telegrams, notes and cards along with recent developments such as text, Twitter and email, is the form of cultural production that has involved and continues to involve more people than any other (Barton \& Hall, 1999; Gerber, 2006; Lyons, 2007). Among four of the six registers along the dimensions labelled 'affective intensity', letters are given higher rank. Moreover, these letters are used to communicate certain types of affective displays that cannot be considered as appropriate in face-to-face interaction.

Besides, communicative drives, letters also serve for building reflective spaces through which human experiences and ideologies can be captured and which also help manifesting identity construction and negotiation processes. Letter writing is held not only as one of the literary genres that can productively be 
employed for presenting data about its writers, but also as a space that could display autobiographical reflection (Boud, Keogh, \& Walker, 1985; Dewy, 1938; Finlayson, 2015; Schon, 1983). The current study specifically analyses the genre of love letters which further demonstrates the shuffling, shifting and shaping process of the writers' identity in the socio-political context of Pakistan from gender perspective.

This research intends to pinpoint the textual features and contextual connotations particularly regarding gender in the love letter writing practices of people in the specific context of Pakistan. Love letter writing is an important social literacy practice, which is preferred over the face-to-face communication because thoughts and feelings may be written down more directly as they come across the author's mind especially in the absence of the concerned reader. Feelings can be more straightforwardly voiced in this way, compared to speaking in the presence of the beloved. Love letters may express feelings within an existing relationship or be aimed to develop relationship, connection or association. So, in this context, this research focuses on the emotive aspects of love letter writing which are one of the main stimuli for writing.

\subsection{Related Researches}

Del Lungo Camiciotti (2014) in his article offers an overview to recent scholarship on epistolary discourse and practices in early modern culture. At the intersection of historical pragmatics and the study of manuscript letters various significant studies may be located such as Williams (2013), who proposes a multidimensional analysis of letters defined as a particular type of written communicative activity that can be best understood by viewing the original sources. When the epistolary manifestation of correspondents' attitudes towards each other is examined through the use of speech acts, rhetorical strategies, and linguistic conventions of letter writing, it is possible not only to hear past epistolary 'voices' (Steen, 1988), but also to shed light on familial and wider social contexts.

According to Nevalainen (2000, p. 38) the social variable of gender has a significant role to play in the debate of supra local features which in the course of time became part of the morphology of Standard English. The CEEC has also been exploited to shed light on the language of daily life in past ages (Nurmi et al., 2009). The language of personal letters has been shown to be close to spoken language in many ways (Biber \& Finegan, 1989, 1992). So, the study of personal correspondence between identifiable individuals, male and female from different geographical locations, has not only provided a rich source of material for the study of language variation and change in the history of English since language change typically emerges from spoken language, but also enabled to reconstruct the interactional use of language in the social contexts of everyday life (Nurmi et al., 2009, p. 1).

Ahearn (2003) has conducted an ethnography she has explored the way in which the villagers of Nepalese community found this love letter writing as a new practice that was situated in their social contexts. Love letters which were previously did not exist in the community got spread in a very short span of time as people adopted this practice as started taking as an important phase of courtship and marriage. This research demonstrated the connection of love with the achievements of the villagers such as they used to communicate and express their feelings regarding education, admiration, appreciation and development in this way.

All the above researches gave the researcher the streamline for research and implied that the current research is a multidisciplinary research based on NLS and sociolinguistics paradigm

\section{Research Methodology}

\subsection{Sampling}

The task was to locate "hidden populations" that the participants that are not readily or easily available. Getting informal personal love letters from the people is a difficult task as such letters carry their personal and secret feelings and thought and people may not want them to publicize. Therefore, I employed snow ball sampling to collect data for this research. For this, I utilized my social contacts within my social networks to attain an access to the target subjects. This technique proved very fruitful in rendering such data which would not have become possible by employing some other sampling technique.

Furthermore, being inquisitive, researcher is of the view that language not only encodes but also to some extent formulates social relationships and personal identities. Such ideologies and identities are most often unfamiliar rather unknown to the language users themselves. Therefore, the relationship between social and personal identities and power structures embedded in the language of informal discourses particularly love letters has always been of great interest to the researcher. Moreover, love letter writing has always been considered as stigmatized literacy practice in patriarchal society like Pakistan, so there found some reluctance on the part of researchers to work on some topics of which people do not want to comment or provide data. Such instinct 
motivated the researcher to investigate the genre of love letter and offer interpretative analysis that contribute to understanding of language within careful descriptions of Pakistani culture and values.

\subsection{Research Method}

This research employs 'Case study Method' for the ideological representation of gender identity (ies) and ideology (ies). A young Pakistani couple (boy of 23 and girl of 18) is taken as a 'Case'. Boy and girl, both are students at post graduate university. The data are comprised of their love letters which are written in their courtship period during the year 2003-2005. The couple has been approached by one of the researcher's very close friends. She got their consent to take their love letters for the research purpose. Having considered love letter writing as stigmatized literacy practice in socio-cultural context of Pakistan, the only reservation the couple had was not to mention their names in the research. For that reason, the pseudo names are used for them; Johny for the boy and Reeta for the girl. These pseudo names are also suggested by the couple itself, because their friends and family used to call them by these names.

\subsection{Data Analysis}

This research employs the ideological model of literacy as defined by Street. Contrary to outdated Marxist (and currently anti-Marxist) sense of 'false consciousness' and simple-minded doctrine he has used the term 'ideological'. Most of the contemporary sociolinguists, anthropologists and cultural scholars support the term and view ideology as a concept which embeds power and authority one the one hand and resistance and creation on the other hand (Street, 1993). The variety of cultural practices which includes language and of course literacy play a substantial role in the construction of such tension. So, in this sense, it is important to understand the study of literacy as an explicit 'ideological' model.

\subsection{Research Questions}

The research answers the following questions:

Q\#01 How does love letter writing as a social literacy practice construct and represent identity (ies) and ideology (ies) of its users particularly regarding gender in socio-cultural context of Pakistan?

Q\#02 Hoe does letter writing as a significant literacy practice signify distribution of social power and hierarchical structure in society like Pakistan with particular regard to gender?

\section{Ideological Analysis}

For Ideological analysis of the data, it has been divided into following categories.

$>$ Title of Endearments

$>$ Sexuality and language

$>$ Identity Construction and Naturalization

$>$ Self-objectification of woman

$>$ Linguistics Style

\subsection{Titles of Endearments}

A word or phrase, one may use, to address or describe someone or something for which he/she feels love and concern is termed as 'Title of Endearment'. People use these terms for many reasons e.g. parents calling their kids or lovers when address each other etc. Many scholars from various fields like discourse studies, sociolinguistics, pragmatics and anthropology are interested in the researches and studies on address titles and forms. This is because, of verbal behavior, address forms comprise a noteworthy part because beliefs, behaviors and social practices of any society are evident in them.

Likewise, address forms reflect concerns and reservations of the users regarding sexuality, race, gender, ethnicity and religion (Dakubu, 1981; Fang \& Heng, 1983; Fitch, 1991; Oyetade, 1995; Afful, 2006). It must also be noted that terms of endearment are coterminous with forms such as endearments, sweet words, sweet talk, affectionate talk, soft words and terms of affection to explore the socio-pragmatic factors that underpin the use of these terms.

Linguistic choices and practices that are prevalent in culture perpetually determine and (re) produce social gender. Meanwhile, the titles and the way of addressing are an essential and established category of it that also substantiate culture special meanings. These titles and forms are loaded with socio-cultural pragmatics of society. Also, they mirror the relationship between the participants (sender-receiver) and reveal the fact that these choices are determined by the historical, cognitive and ideological reality of the particular context. Therefore, in different 
social contexts, different titles and terms are used by different people. Similarly, the linguistic choices and style used by men and women are different representing their respective culture and practices.

In the light of aforementioned arguments, the titles used by Johny and Reeta for each other are analyzed ideologically. The respective titles carry lot of meanings and found influenced by social and pragmatic factors of Pakistani society. The tiles used by Johny for Reeta reflect authority and dominance that a patriarchal man is socialized to develop in him.

There are some vocatives that men employ to call their female partners like; 'my bird', 'my chick' etc. Apparently, such titles seem to be endearments, but actually they implicate the equivalence between females and cute small animals. Likewise, there is a wide variety of words that are included in this category such as; 'doll', 'baby', 'babe', 'chick', 'hen', 'pet', 'flower' and 'petal' and so on. Such titles are also used by women to men, but this happens less frequently and also in particular contexts.

For the detailed analysis, the titles of endearment used by the couple are categorized as:

a) Sexual Titles

b) Edibles

c) Animate Titles and Inanimate Title

\subsubsection{Sexual Titles}

Sexual titles are the titles that are used to depict its user's intentions to develop physical relationship with someone. Johny, in all his letters makes an extensive use of sexual titles that reveals his intentions to have sex with his girl. This is how the patriarchal woman is considered mere as a sexual pleasing object. He addresses Reeta with the titles like: "sexy, hot chic, soft, beautiful, pretty, charming, ever appealing, sundar larki (good looking), cute, gori gori (fair complexioned) etc" (Appendix 4, 5). Such titles demonstrates the primary concern of patriarchal man that is the beauty of a woman. He appreciates and admire her beautiful looks including her lips, eyes, cheeks, hands, feet etc.

Another significant title that he repeatedly uses for Reeta is 'Cat'. He calls her 'My Crazy Cat' (Appendix 3) so many times in his different letters. Using the title of 'cat' relates it with the concept of catcalling. Catcalling is a whistle, suggestive comment or a cry intends to express sexual attraction and admiration. Referring to the sexual connotations associated with the term, Johny writes at one place, 'want to be scratched' and expresses his desire to get closer to his girl.

It is surprising to mention that the titles used by Reeta for her boyfriend show adequate number of sexual titles that is contrary to the stereotypical patriarchal woman. Unlike a stereotypical patriarchal woman, who is socialized to be very shy and inexpressive, Reeta expresses her desire to have physical relationship with her man. Also, she admires his good looks and admits that she gets more attracted towards him by looking at him. She uses the titles like; "Handsome, sexy, dimpled darling, hot, Tasty, Yummy, and Delicious" (Appendix 2)

\subsubsection{Edibles}

Edibles are another striking category of the titles that the couple has used in their letters. 'Honey', 'sweety', 'sweetheart', 'sugar', 'cheesecake' etc., along with wide range of words that are recurrently used by men than women. It implies that the addressee is something very good to eat and is readily available for consumption (Mills, 1995). She defines Tart as:

Tart entered English 1400 from the old French tarte, the name of pastry or pie with a sweet filling.... In the mid nineteenth century tart was applied to a young woman as a term of endearment. It may have been a contraction of, or rhyming slang for, 'sweetheart'. Like honeybun, sweetypie, cupcake and other terms employing a similar image, tart presumably derives from the notion of the supposed and required sweetness in a woman and perhaps from a male view that women are small, quick-to-consume, edible morsels (pp. 234-235).

The titles Johny uses regarding this category are; 'my butter', 'my cream', 'my juicy', 'my strawberry', 'my cheeku' (sapota), 'my delicious', 'my yummy', 'my tasty' 'my honey' etc. (Appendix 4) Such titles are symbolic because they reflect the fragile and weak standing of woman in patriarchal society. They are considered to be used/misused as easily as a slice of cake. Patriarchy socializes woman to bow down in her desires, opinions, values and feelings so readily that a man could take her for granted. Such titles also imply sexual connotations associated with woman, as most of the titles that Johny writes for Reeta are soft and easily consumable fruits and tarts. It symbolizes patriarchal mindset that views woman as a delicate thing which can very easily be swallowed and digested. 
On other hand, Reeta has used different types of titles for Johny. Except few, she barely uses edibles as titles for him. For example, she addresses him as; 'my delicious', 'my Tasty' (Appendix 2) and these are not direct edibles but refer to some food that is enjoyable and delicious. It demonstrates that patriarchal man is socialized to be tough and strong and is offered a great exposure to the outer world. Because of this tough training, they become rigid in their opinion and behavior and not easily consumable as patriarchal woman, who is socialized otherwise.

\subsubsection{Animate and Inanimate Titles}

So far, this category is concerned, Johny uses many animate titles for Reeta which include; animals, birds and flowers names. The titles he uses are; 'my crazy cat', 'my peacock', 'my butterfly'. Among them, one is beautiful pet, and others are precious and colorful birds (Appendix 3).

It shows that patriarchy has great influence on the boy and consciously/unconsciously, he wants to keep his girl with him like a beautiful pet who offers him entertainment and pleasure all the time. Calling woman with animal names is highly ironic and significant in terms of her status and place in society. Animals are the creatures who are not intelligent and sensible enough to look after themselves, think reasonably to take important decisions of their lives. So, the women are considered as dependent, nonsense, unintelligent creature who cannot stand by themselves to take any wise decision of their lives. The specific choice of animals used by Johny is highly significant that constructs particular identity for the patriarchal woman; he calls Reeta by those animal names who are usually kept as pet by people.

Generally, people keep pet for companionship and pleasure. They train according to their own wishes and needs. Sometimes, training gets very tough just to make them learn discipline and the follow the given instructions. This is how language works as a controlling factor to represent embedded identity (ies) and ideology (ies). The metaphorical use of these animal pet titles is highly symbolic as it represents the cognitive approach of people who view woman not as a human being but an animal which can be trained according to their wishes and desires.

The repeated use of "Crazy cat" and "bitch" in most of his letters exemplifies the women being called, treated and considered as animals.

Moreover, Johny repeatedly uses inanimate titles for Reeta. In almost all of his letters, he calls her "my blushing doll" (Appendix 3). The word blushing denotes shyness that is one of the mandatory ingredients of a perfect patriarchal woman. And a doll is a puppet which cannot even move by itself and whose strings are in the hands of its master who moves it according to his own will. Having controlled by external force, a doll as a puppet always remains unable to respond, resist and contest.

Johny says at one place:

I love u yarr!!! Apni jan ko bohat piar s rakhon ga

(I'll keep my love with great care) (Appendix 5)

The patriarchal constructions and representations of femininities and masculinities are clearly depicted in the language used by him. It reveals that woman is considered mere as thing or object not a human being. The choice of word demonstrates that besides having intense love feelings for Reeta, Johny wants to 'keep' Reeta as in his possession. It adds that human beings are not kept somewhere, instead things or pets are kept in possession and then they further need to be taken care and looked after.

Reeta's titles for Johny represent patriarchal woman's imaginative nature. Having influenced by patriarchal mindset she lives in fantasies and idealized world.

She is taught and socialized in the way that one day when she gets married, she has to leave her father's home and her possession would be transferred from one man (her father) to another (her husband) and afterwards, who will be responsible and in charge for her future upcoming life.

She as a true embodiment of a patriarchal woman is also socialized to behave like a dependent and diffident person. So, having such socio-cultural contexts and experiences, she uses the titles like:

My Superman, my only love, my one and only love, my life, the first and last man in my life, my aim, my destination, my husband, my soul, the man without whom I am nothing, the person who is my life, etc etc. (Appendix 1, 5,6)

Such use of titles represents the dependent and insecure nature of a woman. She writes Johny "Superman" which is a fictional and imaginary character in movies who is a savior and has supernatural powers. He can fly also, and he help everyone who is in trouble. Whenever someone is in problem, superman comes out of nowhere and takes that person out of that trouble by killing the villain or monsters. Similarly, possibly, she expects her 
man to be a character like superman who should support and help her in every stage of her life and who should be responsible to bring happiness and comfort in her life

She makes repeated use of my only love, my one and only love, the first and last man in my life (Appendix 1) that is related to her unending effort to ensure her man about her chastity and loyalty that is an obligation for a patriarchal woman. So, she ensures him that he is the only man in her life, by calling him the first man in her life is actually informing him that she has not been in any relationship before him. And she makes him a promise and confirmation when she calls him a last man, that if she is engaged to him, she may never urge to find some other man, no matter what happens next. This is something a man always want to be sure about his woman that is why Reeta has repeatedly used such kind of titles for him. But there is no evidence of such titles in Johny's letters.

Reeta uses titles like, my aim, my destiny which are very important as they represent her as dependent woman whose aim in life is just to find rather hunt a perfect match for herself. Such ideologies and mindset urge her to call Johny her final destination and aim and now she has found him, so she has achieved her target for what she is born, and her search has ended after having Johny in her life.

\subsection{Sexuality and Language}

'Sex' and 'Sexuality' are two different terms; sex comprises only small part of sexuality and is related to the identification of who we are as sexual beings. Even people who do not experience sex are sexual beings. Whereas, sexuality is much more than body parts and sex. Though it contains these things, too but it is not related to body parts only. It establishes gender identity i.e. the sense of being man or woman. Since it is connected with gender identity, it is believed to be constructed and represented through language.

Society plays an important role in socializing people regarding their sexual identity, e.g., men and women are socialized to practice their sexuality in a specific way. It includes identification and awareness of one's gender as man or woman. Media, family, friends, religion, age along with life goals, and self-esteem play a pivotal role in shaping people's sexual selves. Sexual identities and sexual ideologies are constructed through language. Individual personal values, practices and mindset, culture, experience and exposure, spirituality and societal expectations are very much part of it. An obligatory and the most desirable attribute of a patriarchal woman is her beauty and sexuality. Whereas man is appreciated and admired for his intellect, brainpower and skills.

Furthermore, she cannot escape from the restrictions imposed on her regarding her body, face and features. Even if she wants or not, she is always viewed as beautiful and pretty creature with little or no brain. Besides, her sexual expectations are not bound to her apparent body and beauty but also to her innocence and brittleness.

David Lee (1992) defines language as:

Given that language is an instrument for the assignment of the phenomena of human experience to conceptual categories it is clearly not simple a mirror that reflects reality. Rather it functions to impose structure on our perceptions of the world. Language is ... highly selective and in this sense... the process of linguistic encoding involves a significant degree of abstraction away from reality (p. 8).

Keeping in mind the above definition of language, the language used by Johny and Reeta is analyzed very carefully so that it may represent their sexuality respectively particularly in Pakistani context. Such notions are clearly evident in the analysis of sexual titles used by the couple in previous section. In this context, gender is a useful term, since it foregrounds the fact that men and women and femininity and masculinity are produced as different respectively, even though there are some elements which women and men share.

It also entails the concept of sexual objectification of woman which is related to the act of treating woman as mere sexual object. It implies that patriarchal man considers woman as a commodity or an object regardless her personality or dignity as a human being. Reeta being a patriarchal woman is a true embodiment of Objectification theory (Fredrickson \& Roberts, 1997) that sexually objectifies female body and offers theoretical underpinnings for comprehending the experience of being a woman in patriarchal culture. The language used by Johny in his letters also exemplifies the same patterns. He writes in one of his letters:

\section{Darling u r so cute and sexy that I can't resist to love u (Appendix 5).}

Here, Johny finds Reeta extremely innocent and sexy, so for this reason he could not resist loving her. He views her apparent beauty more tempting and attractive than her inner qualities, so he gives all credit to her outer looks for loving her so intensely. Reeta is viewed as an object of sexual desire that does not seem to have personal emotions and feelings. At another place, Johny mentions and appreciates her body parts. He expresses his feelings about her looks and tells her what he feels when he touches her. He writes;

Holding your hand is the promise to be your forever partner in the way of life.... Kissing your forehead is 
like the state of being responsible...Kissing your eyes is the assurance of my love... (Appendix 4)

Likewise, he mentions her lips, neck, cheeks etc. (Appendix 4) as he says:

Holding you... kissing you is the only way to express my love... (Appendix 4)

Although, there could be various ways to let someone know about one's feelings, but he thinks that he can only express the intensity of his love just by holding and kissing her. Such linguistic choices imply that patriarchy objectifies woman by equating her worth with her body appearance, body parts and their sexual functions.

So far sexuality in Reeta's letters are concerned, the woman's perspective is very much evident in her writings.as she writes;

\section{Oh God! Kahan ho tum????(O Gosh! Where $\mathrm{r} u$ ?)}

Come to me soon. Wanna kiss u and hug u. (Appendix 3)

This is contrary to patriarchal woman who should be completely dependent on her man for this sexual desire. Instead, she expresses her intentions to get closer with Johny and have relationship with him in most of her letters. It reveals how such writings construct and represent embedded identity (ies) regarding femininities and masculinities.

\subsection{Identity Construction and Naturalization}

The language used by Johny highly demonstrates how gender politics of inequality are played in such highly sexualized discourse of love letters. If viewed as apolitical and common sense, the description of sexual titles is highly ideologically loaded, asserting male hegemony and 'Othering' the female.

Referring to the aforementioned argument, it can also be elaborated that such hegemonic and political use of language make these socially constructed ideologies and identities extensively viewed as natural. So, the people who are well aware and conscious of these political and hegemonic inequity and exploitation of language make common man/woman pass through the process of Naturalization deliberately. Therefore, the so-called naturalized ideologies seem natural for the layperson and he/she behaves and performs in the same way by conforming these practices in socio-cultural contexts.

It can also be argued here that the 'Common sense' usage of these highly gendered and sexualized verbal titles is not politically innocent and meaningless. These are part of the culturally and socially ingrained and institutionalized construction of gendered subjectivities. Men and women from the very beginning, are socialized in a way to behave in a certain stereotypical manner that in turn, construct culturally specific femininities and masculinities.

This is evident when he says that he feels himself responsible here:

Whenever I kiss on your forehead is like the state of being responsible ... for guiding you the ways and providing you the security. (Appendix 4)

It also implies all the stereotypes which has been associated to men in patriarchal society. It represents masculinities prevalent in Pakistan where man is supposed to look after his family in terms of financial support, moral support, decision making etc. it shows that not only femininities, but masculinities are also socially constructed and are made natural by the society through discursive practices and patterns.

In other words, when a man is having a relationship with some woman, he owes her so completely that there is no room for her to take any kind of decision independently without taking permission from her so-called Masters. They keep them as their property and think themselves as their masters.

Language usage thus becomes the super structural semiotic tool where the appearance of subjects in 'real life' is embedded in these gendered cultural codes which both shape their behavior, not apolitical and transparent, but rather how they are constructions which encode particular patriarchal views.

\subsection{Self-Objectification of Woman}

Fredrickson and Roberts (1997) asserted that women to varying degrees internalize this outsider view and begin to self-objectify by treating themselves as an object to be looked at and evaluated on the basis of appearance. Self-objectification manifests in a greater emphasis placed on one's appearance attributes (rather than competence-based attributes) and in how frequently a woman watches her appearance and experiences her body according to how it looks (McKinley \& Hyde, 1996; Noll \& Fredrickson, 1998)

More specifically, Fredrickson and Roberts (1997) postulated that self-objectification can increase women's anxiety about physical appearance (i.e., fear about when and how one's body will be looked at and evaluated); 
reduce opportunities for peak motivational states or flow; diminish awareness of internal bodily sensations (e.g., hunger, sexual arousal, stomach contractions); increase women's opportunities for body shame (i.e., the emotion that results from measuring oneself against a cultural standard and coming up short); and increase women's anxiety about their physical safety (e.g., fears about being raped), which in turn can lead to disordered eating, depression, and sexual dysfunction.

The element of self-objectification is very much evident in the language used by Reeta in her letters especially the way she has addressed herself in the closing lines of every letter where the addresser writes his/her identity in terms of name or something else. In all her letters, the words she, has used for herself are:

Yours sexy, yours crazy cat, your strawberry, your, sweetie pie, you honey, your beautiful etc etc. (Appendix 2, 5, 6)

These all are the titles which are used by Johny for her, and instead of contesting these titles, she happily accepts all these and endorse Johny in this regard giving him her acknowledgement that she is happy with the inferior status given to her by him. Thus, reflecting the patriarchal woman's complete submission and subordination to her master.

It is also evident when she says:

I will prove myself the best wife and partner, I'll look after you, your home and your family as well. I will make your home a paradise on earth. (Appendix 5)

The above lines are highly symbolic as she herself objectifies herself very happily that she is an object of pleasure for him and his family and she is going to prove herself in order to make a place in his heart and home. Moreover, she says that she will make his home not her or our home a paradise. She admits in her sub-subconscious that the home where she will be living after her marriage will be her husband's home not hers. Another significant and notable point that in patriarchal culture there is long house system that is also called undivided family, joint household, and extended family system is a large undivided family where more than one generation live together in a common house. All the members are expected to make some financial contribution to the common fund, share common rights in the household property, eat the food made at the common kitchen, and make their daily expenditure from common fund. Johny also lives in such kind of Joint family system and in such family systems, women are supposed to look after not only their own husbands and children but also all the family members. Having known these traditions and conventions of Joint family system, Reeta ensures Johny that she will look after not only him but also his all family members because she knows that a patriarchal man always gives priority to his parents and siblings over his wife. Here comes the concept of "Othering". He considers his parents and siblings and even his children his family but not his wife.

\subsection{Love Letter Writing and Power Relations}

Like identity, and ideology, power structures are also re(produced), represented and established through writings. Such hegemonic power relations are resulted by behaviors, attitudes and set of roles which are determined by the use of language in society. It works at all levels in society from close domain of the household to the highest level of management.

This hierarchy of interrelationship that exists within controlling agency is a product of language that is political. Such hegemonic patterns are evident in the writings of Johny and Reeta as well. Johny says in one of his letters:

Honey! Whatever I have achieved is only because of your support and I really congratulate you that you have successfully elevated my personality. (Appendix 7)

It reflects the subordinate and supporting role of women in society, thus allocating man controlling and dominating position. Further, it reveals that a man can only be 'Achiever', when he congratulates his beloved for providing him enough support to become one. He acknowledges her effort that she makes in order to support him, so that she may continue doing so. Such acknowledgements and appreciation tempt her to continue putting her efforts to make him happy and comfortable. This is how her subordinate identity is developed through manipulative use of language and she happily admits her subordinate role.

Power, Authority and control are associated rather served to man in patriarchal society. They are socialized to take hold of their family as fathers, brothers, husbands and sons. They have internalized such mindset and are very much aware of their power and authority right from the beginning. Subsequently they exercise their power whenever and wherever they think it is needed. As Johny writes:

I always want to be with you to take care of you. (Appendix 7)

At another place he writes: 
I'll give you a better life that I have planned for us. (Appendix 7)

The use of first-person pronoun is highly ironic and significant when he promises his girl to provide her a better life which he himself has planned for her. It implies that power and decision making belong to him and she is bound to accept whatever he plans for her. Such masculinities are also constructed discursively in society and man is socialized to behave this way. Similarly, he says:

I love u yar!!! Tumaray mazay karwane hain

(I love you! I will let $\mathrm{u}$ enjoy yourself) (Appendix 7)

Apparently, he expresses his deep love for his girl and promises her to provide her the best life ahead and he really wants her to be cheerful being with him. But the deep structure of his text depicts power, authority and dominance of which he himself might be unaware.

Power is very much evident here when he feels himself responsible to provide his girl a happy and comfortable life. Authority can be seen in the tone that reflects his self to be aware of his power to make her feel happy or sad. And being very generous he allows her to live her life happily.

Language functions not only to represent ideologies and identities but also to construct these. Such statements given by Johny would have everlasting influence on Reeta's mind. Consequently, she would unknowingly accept and admit the power exercised by Johny and her subordinate role in a relationship. Such process leads her think (if previously she did not) that only her future husband has an authority and power to keep her happy or unhappy, so she is supposed to please him.

At some place, he says:

You always do care of me and done things upto my expectations though beyond my expectations. (Appendix 8)

The language used by Reeta also reflects hierarchal distribution of power in the society. The inferior and subordinate role of woman is visible in the language structures used by her. Repeatedly, she surrenders herself by accepting her subordinated and dominated position before him. She willingly gives her consent to be treated according to his own will. It also implies that she has already made up her mind that from onward she gives up in her all her desires, wishes and dreams, thus depriving herself of all decision-making power.

Me saari ap ki hun.

(I am all yours)

I have entirely given myself $2 \mathrm{u}$, totally submitted. I always want to make $u$ happy. (Appendix 5)

Furthermore, in almost every letter, she confesses to be totally dependent on him for all the happiness and comforts. She writes:

Its only "U" Johny. Only u, on whom my all life, aims, plans, wishes, expectations, my smile, my happiness, my sorrows depends only on u (Appendix 1)

Woman's identity as a sensitive, emotional and helpless being is emerged in these letters. Although Reeta is an educated girl, even then, she appears in dependent and subordinate position in her writings. Representing true spirit of patriarchy, she lets herself down before her man and requests him time and again in her letters to take care of her and feelings. It is quite interesting to mention the fact that when the date of their wedding gets fixed, there is a noticeable shift in her expression. She becomes humbler and subordinate in her style. It represents her insecurities regarding marriage as an institution in patriarchal culture like Pakistan. It is highly symbolic in terms of identity crisis. She suffers from identity crisis, her identity is going to be fluctuate; from a girlfriend/fiancée, she is going to become a wife. Patriarchy does not allow woman to break up with her husband after her marriage at any cost. For a woman, being divorced/separated, is considered as highly stigmatized in such culture and such women are always looked down and assumed 'Bad woman' in society. Keeping in view the consequences, women are pressurized by their family to carry on the relationship, no matter how much harm it causes them at physical or mental level. Perhaps, she is in dilemma and feels herself helpless and this might be the reason for her being extra polite and humble to Johny. She writes:

I have lost everything for $u$.

Now I can expect only from u plzzzz do respect my feelings coz now u have authority

$\mathrm{U}$ can make me smile, $\mathrm{U}$ can make me weep

I am totally dependent on $\mathrm{u}$ 
Do trust me yaar!! Do take care of me, my feelings

Do understand me, Do love me more n more

I only need ur love and favour. (Appendix 9)

Such expression reveals Reeta's inner fears and insecurities regarding marriage. Another interesting point arises here when there appears some hesitation and resistance on her part; she confronts her position by telling Johny that she never wished to be changed for someone. But now following patriarchal customs and traditions, she is supposed to get changed according to her husband's will. It is important to bring attention that such change in habits and behaviours is not expected from a patriarchal man. In fact, a healthy relationship demands compromises and adaptability from both partners.

I never wished to do the thing which now I wish to do $4 \mathrm{u}$. I never wanted to get change for sum1.But 4 "U", I want to change into sum1 whom "U" Idealize. I really want to be upto URS standards. (Appendix 9)

Moreover, at the same time this is also a very significant fact that writing love letters by women is a hidden literacy in Pakistan which is also considered as stigmatized in this patriarchal society. By writing their inner feelings and emotions to their beloved they try to experience the autonomy of power which they cannot practice explicitly in the public domain of men.

Again, so far power relations between men and women are concerned, the same concept is applied here. Women being dominated and ruled by men under the realm of patriarchy suffer or made suffer from inferiority complex and that's is why she always strive for having fair and white complexion. She is also appreciated rather encouraged to put her best efforts to get white complexion. So, this is the embedded ideology that is being represented time and again in the language used by both the boy and the girl.

\subsection{Linguistics Style and Identity Constructions}

There is a remarkable difference in the language structure used by the boy and girl constructing and representing manifold ideologies and identities. The analytical framework of this particular research reveals that its language has constructed masculinities and femininities regarding the roles of men and women in Pakistan respectively. The linguistic style employed by both genders is enriched with enshrouded and embedded meanings in this case study and it reveals the assigned roles to each other which depict explicitly the gender differences of the patriarchy and constructing different identities for both of them.

\subsubsection{Literary Style}

The language used by Johny and Reeta reveals that both of them are educated and have well enough knowledge of literary language. They make an extensive use of figures of speech that include similes, metaphors, personifications, hyperbole etc etc. In their letters, they use the language skillfully to express their feelings and thoughts. Furthermore, the way they quote lines from different sources also represent their wonderful taste and understanding of literature. At one play. The boy writes:

... Like an angel you always do care of me and do things up to my expectations rather beyond my expectations... (Appendix 3)

In the above-mentioned line, he uses the metaphor of "angel" as angels are the purest thing and they are believed to take care of people and protect them from any adversity. Therefore, by admiring such qualities he makes his girl realize that she is supposed to be caring and helpful person otherwise she may not be appreciated by him. It also shows that he has got some expectations from her regarding his care and she is bound to come up to his expectations as it is her duty and obligation to take care of him.

Similarly, at another place he says:

You exposed the world of happiness that was never been known, you opened the door of a fabulous, exciting and thrilling world to me. (Appendix 7)

It implies that the love the boy feels for the girl is just because of the things she does for his care and pleasure not for some good quality or nature she possesses as a person. It also shows the expected role of a woman in a man's life that she is supposed to bring thrill and excitement in different ways to keep him happy and never let him get bored.

Johny and Reeta both make an extensive use of rhetorical language in their letters that gives an imaginative and poetic impression. Reeta writes

"Whenever I look at you, my heart skips a beat." 
"Love is what you mean to me, and you mean everything."

"Being with you, I feel as if in a single life time, I've known the joy of thousand years."

"You hold the key to my heart."

"Knowing you is loving you." (Appendix 2)

Then Johny says:

"Spending time together is a great feast for me"

"You are Rainbow of my life, as you have brighten my days and enlighten my nights like a shooting Star." (Appendix 4)

"You captured my heart and left me spell bound ever since." (Appendix 7)

\subsubsection{First and Third-Person Narration}

Another striking feature is an extensive use of First-person pronoun by Johny and third person pronoun by Reeta. It is highly significant referring to Tannen's difference Theory that claims the differences in the linguistic style of men and women reflecting their ideology (ies) which is constructed discursively over the period of time. By Using a first-person pronoun Johny as a narrator takes all the responsibility of the said discourse which can put $\mathrm{him} / \mathrm{her}$ to a challenging situation. So, it requires more accuracy and correctness that brings confidence to the narrator and he owes the narration or discourse. Moreover, it shows authority and dominance that provides him confidence to owe his statements.

The use of third person pronouns by the girl is also significant in the sense that such pronouns do not put complete responsibility on the writers. There could be different reasons for using third person narration. Firstly, it shows the distance and detachment that make any piece of discourse look natural and real without any subjectivity. So, it might be the way to express her true love and emotions that cannot be questioned or doubted.

It is an indirect way to communicate thoughts and feelings as it implies that writer is not much confident and sure to take all the responsibility of whatsoever is being said. She keeps herself on the lower status and gives privilege to the addressee by not directly using his name as if he could be annoyed or would not be able to make her wishes come true. Therefore, there is an element of submissiveness in the way she uses language.

The third person narration is more objective than subjective giving the readers an impression that someone else tells the said discourse and the portrait he/she paints will be far more accurate and probably far less flattering.

... He, who always takes care of me, my wishes and desires... He's the first and last person with whom I find comfort. Whenever there is something wrong, something gloomy, he always makes it fine for me, and always makes me smile, I love him, I love him so much ... (Appendix 1)

She considers herself a submissive, dependent and a helpless person and who herself relinquishes all the power and authority to her man and makes him realize that being a man he is supposed to take care of all her comforts and emotions.

The lines also reflect the idealized qualities of a patriarchal man expected from a patriarchal woman that she always wants her man to take care of her and again depict the subordinate and dependent role of a woman as she is unable to take care of herself and needs someone else to look after her. In addition to, it reveals the expected role of a man that is to make everything fine when needed.

\subsubsection{Roles Assigned to Men and Women Through Adjectives}

The adjectives used by Johny and Reeta clearly expresses the prevalent gender ideologies and identities in Pakistan. A girl in Pakistan is supposed to be innocent and shy and they are not supposed to be well-aware and confident as it is evident from the adjectives used by the boy for his girlfriend. He appreciates and likes these attributes in her as he calls her this way.

Similarly, the use of adjectives by Johny and Reeta is very much symbolic as by using adjectives for each other, they have assigned some roles which reflects the true spirit of patriarchy.

\begin{tabular}{ll}
\hline Adjectives used by Johny for Reeta & Adjectives used by Reeta for Johny \\
\hline Blushing doll & Handsome \\
Most beautiful & Superman \\
Sweet strawberry & Practical \\
Sexy & Responsible \\
Innocent & Rational \\
\hline
\end{tabular}




\begin{tabular}{ll}
\hline Hot & Supportive \\
Cute & Educated \\
Crazy cat & Perfect partner \\
Charming & Best companion \\
Soft & Best friend \\
Gori girl(fair) & Intelligent \\
Shy & Well aware \\
Sundar Larki(pretty) & Amazing \\
Pretty wife & Romantic \\
Courage & Ideal lover \\
Strength & Last destination \\
\hline & \\
\hline Cook & Protector \\
Supportive & Savior \\
Helper & Financial supporter \\
Nurse & Decision maker \\
Wife & husband \\
Mother & \\
Daughter in law & \\
\hline
\end{tabular}

\section{Conclusion}

An extensive Ideological analysis of love letters reveals the re (production), manifestation of identity (ies) and ideology (ies) in the genre of love letters from gender perspective. It supports the contextual theory of literacy and views love letters as loaded with cultural and social identity (ies) and ideology (ies). It represents that the messages presented in love letters are particularly sensitive to changes within social hierarchy of patriarchal society like Pakistan. The writings of the couple do not only express their love feelings towards each other but also reveals the ideologies and identities concerning gender constructions which are embedded in the language.

\section{References}

Afful, J. B. A. (2006b). Address terms among university students in Ghana: A case study. Language and Intercultural Communication, 6 (1), 76-90. https://doi.org/10.1080/14708470608668909

Ahearn, L. M. (2003). Writing desire in Nepali love letters. Language \& Communication, 23(2), 107-122. https://doi.org/10.1016/S0271-5309(02)00046-0

Alleana, M. M. F., Jeffrey, H. K., \& Daniel G. L. (2018). Emotional disclosure and emotion change during an expressive-writing task: Do pronouns matter? Current Psychology. https://doi.org/10.1007/s12144-018-0094-2

Barton, D. (1994). Literacy: An Introduction to the Ecology of Written Language. Oxford, UK: Cambridge \& USA: Blackwell Publishers.

Barton, D. (2001). Directions for literacy research: Analyzing language and social practices in a textually mediated world. Language and Education, 15 (2 \& 3), 92-104. https://doi.org/10.1080/09500780108666803

Barton, D., \& Hall, N. (1999). Letter Writing as Social Practice. Amsterdam: Benjamins. https://doi.org/10.1075/swll.9

Biber, D. (1986). Spoken and written textual dimensions in English: Resolving the contradictory findings. Language, 62, 384-414. https://doi.org/10.2307/414678

Block, D. (2007a). Second language identities. London: Continuum.

Block, D. (2007b). The rise of identity in SLA research, post Firth and Wagner. Modern Language Journal, 91, 861-874. https://doi.org/10.1111/j.1540-4781.2007.00674.x

Block, D. (2009). Identity in applied linguistics: The need for conceptual exploration. In Li Wei \& V. Cook (Eds.), Contemporary Applied Linguistics (Vol. 1, pp. 215-232). London: Continuum.

Boud, D., Keogh, R., \& Walker, D. (1985). Reflection, turning experience into learning. London: Kogan Page.

Chafe, W. L. (1982). Integration and involvement in speaking, writing and oral literature. In D. Tannen (Ed.), Spoken and written language: exploring orality and literacy (pp. 35-53) (Advances in Discourse Processes Series, 9). Norwood, NJ: Ablex. 
Chafe, W. L., \& Danielewicz, J. (1987). Properties of spoken and written language. In R. Horowitz \& S. J Samuels (Eds.), Comprehending oral and written language (pp. 83-113). New York: Academics Press.

Dakubu, K. M. E. (1981). One Voice: The Linguistic Culture of an Accra Lineage. Leiden: African Studies Centre.

Del Lungo, C. G. (2014). Letters and Letter Writing in Early Modern Culture: An Introduction. Journal of Early Modern Studies, 3.

Devito, J. A. (1996). Psycho grammatical factors in oral and written discourse by skilled communicators. Speech Monographs, 33, 73-76. https://doi.org/10.1080/03637756609375483

Duff, P. (2012). Issues of identity. In S. Gass \& A. Mackey (Eds.), The Routledge handbook of second language acquisition (pp. 410-426). London: Routledge.

Fang, H., \& Heng, J. H. (1983). Social changes and changing address norms in China. Language in Society, 12, 495-507. https://doi.org/10.1017/S0047404500010216

Finlayson, A. (2015). Reflective practice: Has it really changed over time? Reflective Practice, 16, 717-730. https://doi.org/10.1080/14623943.2015.1095723

Finnegan, R. (1988). Literacy and orality. Oxford: Basil Blackwell.

Fitch, K. L. (1991). The interplay of linguistic universals and cultural knowledge in personal address: Columbian Madre terms. Communication Monographs, 58, 254-272. https://doi.org/10.1080/03637759109376229

Frattaroli, J. (2006). Experimental disclosure and its moderators: A meta-analysis. Psychological Bulletin, 132, 823-865. https://doi.org/10.1037/0033-2909.132.6.823

Fredrickson, B. L., \& Roberts, T. (1997). Objectification theory: Toward understanding women's lived experiences and mental health risks. Psychology of Women, 21, 173-206. https://doi.org/10.1111/j.1471-6402.1997.tb00108.x

Freire, P. (2000). Pedagogy of the oppressed (30th anniversary ed.). New York: Continuum.

Frisina, P. G., Borod, J. C., \& Lepore, S. J. (2004). A meta-analysis of the effects of written emotional disclosure on the health outcomes of clinical populations. The Journal of Nervous and Mental Disease, 192, 629-634. https://doi.org/10.1097/01.nmd.0000138317.30764.63

Gee, J. P. (1996). Social linguistics and literacies: ideology in discourses (2nd ed.). London: Taylor \& Francis.

Gerber, D. (2006). Authors of Their Lives. New York: New York University Press.

Gillogly, K, (1984). A comparison of letter writing in some non-western societies. Unpublished typescript, Department of anthropology, University of Hawaii.

Goffman, E. (1987). Gender Advertisements. NY, Philadelphia: Harper \& Row.

Heath, S. B., \& Street, B. V. (2008). On ethnography: approaches to language and literacy research. New York: Teachers College Press.

Heath, S. B. (1983). Ways with Words. Cambridge: CUP. https://doi.org/10.1017/CBO9780511841057

Herbert, C., Bendig, E., \& Rojas, R. (2019). My Sadness - Our Happiness: Writing About Positive, Negative, and Neutral Autobiographical Life Events Reveals Linguistic Markers of Self-Positivity and Individual Well-Being. Frontiers in Psychology, 9. https://doi.org/10.3389/fpsyg.2018.02522

Kennedy-Moore, E., \& Watson, J. C. (2001). How and when does emotional expression help? Review of General Psychology, 5, 187-212. https://doi.org/10.1037/1089-2680.5.3.187

Licoppe, C (2004). 'Connected' presence. Environment and Planning D: Society and Space, 22, 135-156. https://doi.org/10.1068/d323t

Lyons, M. (ed.) (2007). Ordinary Writings, Personal Narratives. Bern: Peter Lang.

McGarry, K. (1991). Literacies, communication and Libraries. London: Library Association Publishing Ltd.

McKinley, N. M., \& Hyde, J. S. (1996). The Objectified Body Consciousness Scale: Development and validation. Psychology of Women, 20, 181-215. https://doi.org/10.1111/j.1471-6402.1996.tb00467.x

Mikulecky, B. (1985). The Pastron letters: An example of literacy in the fifteenth century. Unpublished typescript, School of Education, Boston University.

Mills, S. (1995). Feminist Stylistics. USA, Canada: Routledge. 
Mulkay, M. (1985). Agreement and disagreement in conversations and letters. Text, 5, 201-227. https://doi.org/10.1515/text.1.1985.5.3.201

Nevalainen, T. (2000). Gender Di erences in the Evolution of Standard English. Evidence from the Corpus of Early English Correspondence. Journal of English Linguistics, 28(1), 38-59. https://doi.org/10.1177/00754240022004866

Noll, S. M., \& Fredrickson, B. L. (1998). A mediational model linking self-objectification, body shame, and disordered eating. Psychology of Women, 22, 623-636. https://doi.org/10.1111/j.1471-6402.1998.tb00181.x

Norton, B. (2010). Language and identity. In N. Hornberger \& S. McKay (Eds.), Sociolinguistics and language education (pp. 349-369). Bristol, UK: Multilingual Matters. https://doi.org/10.21832/9781847692849-015

Norton, B., \& Toohey, K. (2011). Identity, language learning, and social change. Language Teaching, 44, 412446. https://doi.org/10.1017/S0261444811000309

Nurmi, A., Nevala, M., \& Palander-Collin, M. (2009). The Language of Daily Life in England (1400-1800). Amsterdam (NL)-Philadelphia (PA): John Benjamins. https://doi.org/10.1075/pbns.183

Ong, W. J. (1967). The presence of the word. New Haven: Yale University Press.

Oyetade, S. O. (1995). A sociolinguistic analysis of address forms in Yoruba. Language in Society, 24, 515-535. https://doi.org/10.1017/S004740450001900X

Pennebaker, J. W. (2018). Expressive Writing in Psychological Science. Perspectives on Psychological Science, 13(2), 226.

Pennebaker, J. W., \& Chung, C. K. (2007). Expressive writing, emotional upheavals, and health. In H. Friedman \& R. Silver (Eds.), Handbook of health psychology (pp. 263-284). New York: Oxford University Press.

Redeker, G. (1984). On differences between spoken and written language. Discourse Processes, 7, 43-55. https://doi.org/10.1080/01638538409544580

Rubinstein, D., \& Gajdusek, D. C. (1970). A Study in nascent literacy: neo-Melanesian correspondence from a Fore, New Guinea youth. Bethesda, MD: Section of Child Growth and Development and Disease patterns in Primitive Cultures, National Institute of Neurological Disease and Stroke, National Institute of Health.

Schön, D. A. (1983). The reflective practitioner. London: Temple Smith.

Scribner, S., \& Cole, M. (1981). The psychology of literacy. Cambridge, Mass: Harvard University Press. https://doi.org/10.4159/harvard.9780674433014

Smyth, J. (1998). Written emotional expression: Effect sizes, outcome types, and moderating variables. Journal of Consulting and Clinical Psychology, 66, 174-184. https://doi.org/10.1037/0022-006X.66.1.174.

Street, B. (1984). Literacy in Theory and Practice. Cambridge, UK: CUP.

Street, B. V. (ed.). (1993). Cross-Cultural Approaches to Literacy. Cambridge: CUP.

Street, B. V. (ed.). (1995). Social Literacies: Critical Approaches to Literacy in Development, Ethnography and Education. London \& NY: Longman.

Tannen, D. (1982a). The myth of orality and literacy. In W. Frawley (Ed.), Linguistics and literacy (pp. 37-50). New York: Plenum Press. https://doi.org/10.1007/978-1-4615-9302-7_3

Tannen, D. (1982b). Oral and Literate strategies in spoken and written narratives. Language, 58, 1-21. https://doi.org/10.2307/413530

Wacjman, J (2008) Life in the fast lane? Towards a sociology of technology and time. British Journal of Sociology, 58, 59-76. https://doi.org/10.1111/j.1468-4446.2007.00182.x

Williams G. T. (2013). Women's Epistolary Utterance. The Study of the Letters by Joan and Maria Tynne, 1575-1611. Amsterdam (NL)-Philadelphia (PA), John Benjamins. https://doi.org/10.1075/pbns.233 
Appendix 1 (Full appendices keep highly sensitive and confidential data, and would be provided on permission)

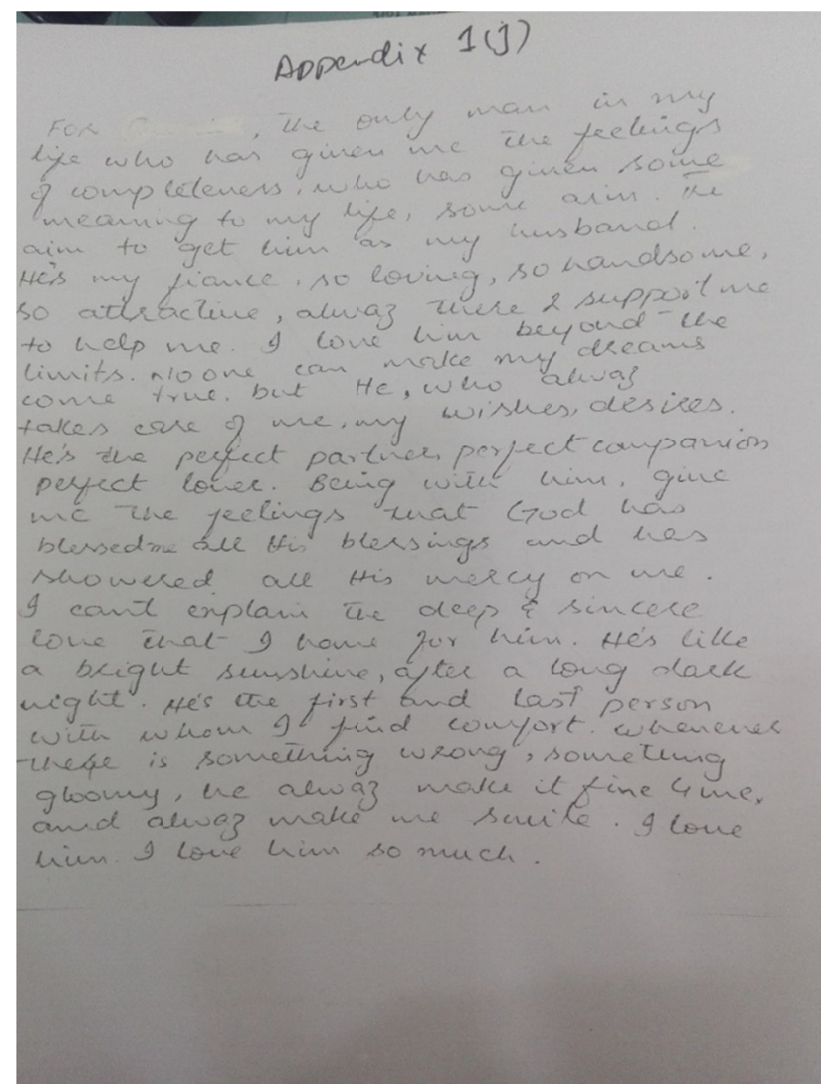

Appendix 2 (Full appendices keep highly sensitive and confidential data, and would be provided on permission)

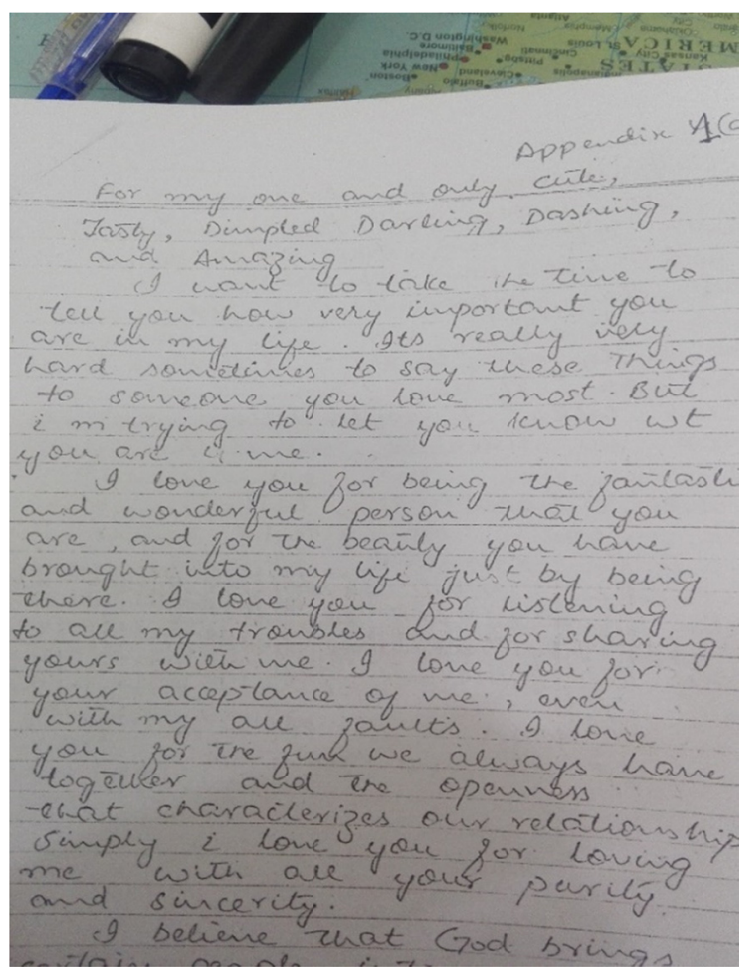


Appendix 3 (Full appendices keep highly sensitive and confidential data, and would be provided on permission)

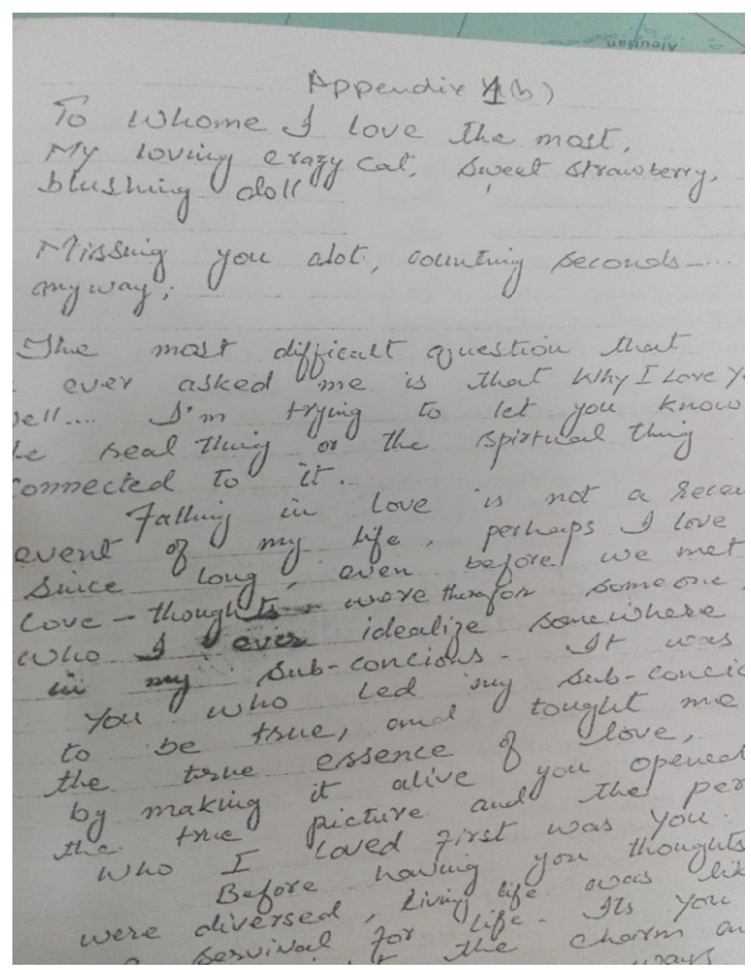

Appendix 4 (Full appendices keep highly sensitive and confidential data, and would be provided on permission)

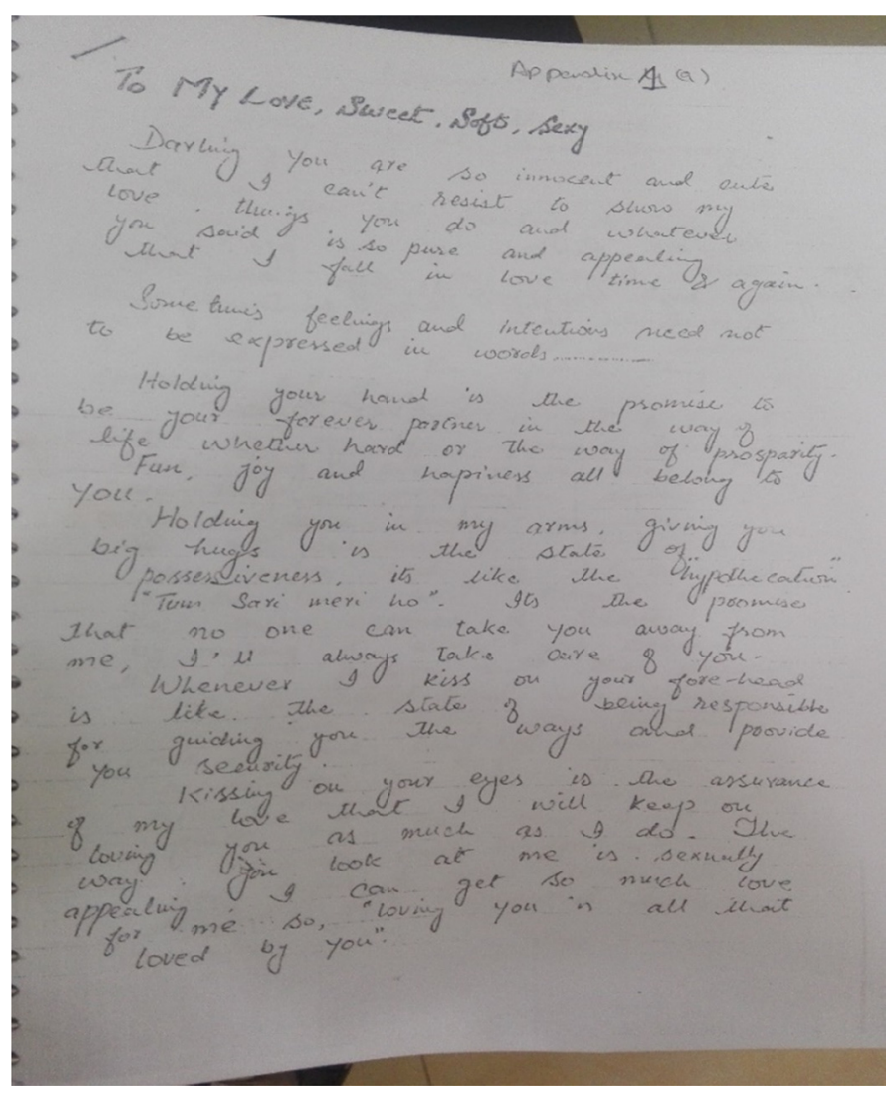




\section{Copyrights}

Copyright for this article is retained by the author, with first publication rights granted to the journal.

This is an open-access article distributed under the terms and conditions of the Creative Commons Attribution license (http://creativecommons.org/licenses/by/4.0/). 